\title{
Understanding Car Ownership Motivations among Indonesian Students
}

\author{
Prawira F. Belgiawan ${ }^{1}$, Jan-Dirk Schmöcker ${ }^{1}$ and Satoshi Fujii ${ }^{1}$ \\ ${ }^{1}$ Department of Urban Management, Kyoto University, Japan. \\ Email: belgiawan@trans.kuciv.kyoto-u.ac.jp
}

\begin{abstract}
Car and motorcycle ownership levels are increasing rapidly in South-East Asian developing countries leading to unsustainable developments. In this paper we focus on car-ownership motivations in Bandung, Indonesia where cars have become the main contributor to traffic congestion. We suggest that attitudes towards cars are important to explain car ownership trends. Using data from 500 undergraduate students from one university in Bandung this study constructs five factors regarding car perception through principle component analysis: symbolic/affective, arrogant prestige, independence, comfort, and social/env. care. These five factors plus some socio-demographic variables, such as monthly income, are used as explanatory variables for modelling car ownership using structural equation modelling. Our results suggest that primarily independence, arrogant prestige and some socio-demographic variables significantly influence car purchase decision. We discuss tentative implications for transport policy, given the limitations of our sample.
\end{abstract}

Keywords: car ownership, developing countries, attitudes towards cars, structural equation modelling

\section{INTRODUCTION}

Car ownership levels are increasing rapidly in many developing countries. Increasing income levels allow in particular citizens of the major cities to purchase more and larger vehicles. One particular 
Car Ownership Motivations Among Indonesian Students trend of South-East Asian countries is the upgrade process from current motorcycles owners to purchase cars. Van et al (2009) show that this trend will lead to significantly increasing congestion levels in Hanoi and similar developments can be expected in several other major South-East Asian cities. Other negative side effects, such as air and noise pollution, accidents and land-use developments trends are also well known.

In Indonesia and other developing countries this trend towards more and larger vehicles appears to keep continuing despite the lower average speeds of cars compared to motorcycles in the already congested cities and despite the well observable other environmental side effects. Indonesia, with a total population of 240 million people, is the world's fourth most populous country (United Nation, 2011).In many islands of the country the number of motorized vehicles rapidly increases according to Indonesian Central Agency of Statistics (2013): In 1987 Indonesians owned around 6 million motorcycles, in 1995 ten million and by 2011the 80 million motorcycles mark has been reached. Car numbers also keep increasing, though not as fast as motorcycle numbers. In 1987 there were around 1 million cars and by the end of 2011there were already 10 million private cars on Indonesian streets (Figure 1).

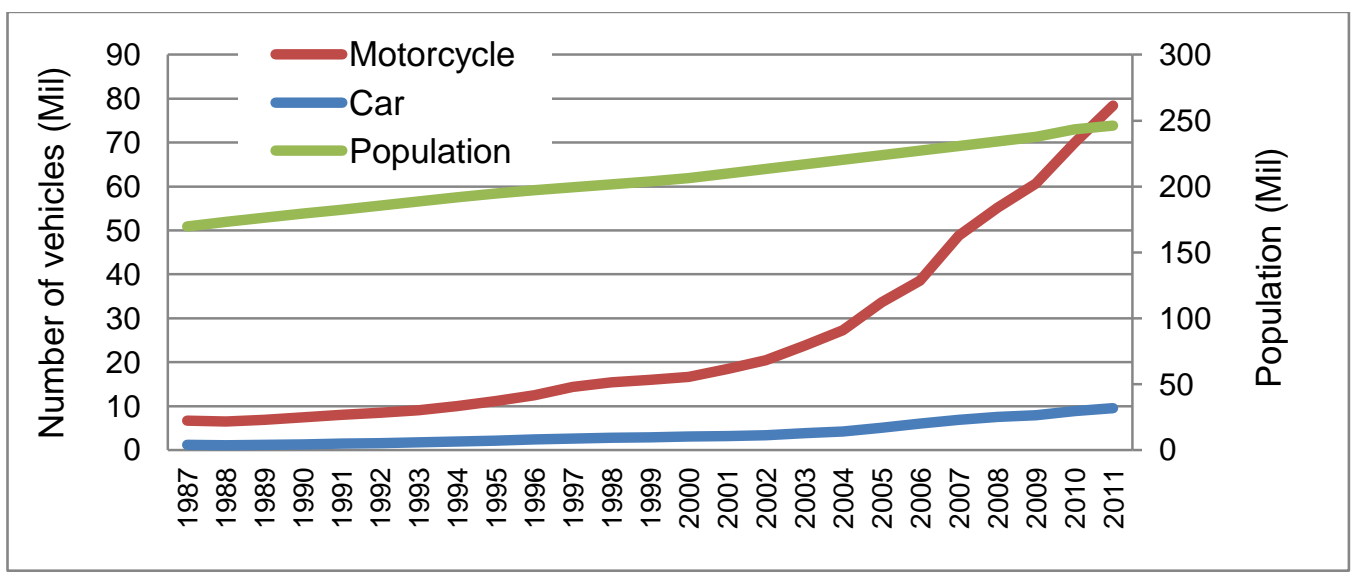

Figure 1. Population and Motorized Vehicles in Indonesia 1987-2011. Source: Indonesia Central Agency of Statistics (2013)

Although the number of motorcycles exceeds the car numbers still by a factor eight, the recent increase in cars are the main cause of traffic congestion. In Bandung, the city this paper will focus on, car ownership levels reached 115.2 cars/thousand people in 2010 (Bandung City Government, 2010) 
Car Ownership Motivations Among Indonesian Students

with rapid continuous growth expected. Furthermore, the trend towards more cars is difficult to control in Indonesia as almost all cities in Indonesia, except for Jakarta, do not have an advanced mass transportation system such as bus rapid transit (BRT). In Bandung, according to Joewono and Kubota (2005), 61.2\% of public transport (PT) is operated in form of Paratransit (Angkot) while the remainder is bus, taxi and rickshaw.

Our aim in this paper is to break down persons' motivations to purchase cars in order to understand how one possibly can induce a shift towards more sustainable modes. Our hypothesis is that not just income but also attitudes towards cars can explain car purchases and travel behaviour. This is in line with research on soft transport policy measures such as "mobility management" where it is found that through communicative methods individual attitudes can be influenced, sustainable habits can be formed and a change in travel behaviour is possible (e.g. Gärling et al, 2001; Fujii and Gärling, 2003; Taniguchi et al, 2007).

According to Fujii and Gärling (2003), the increase in frequency of using a travel mode causes the development of a habit of using this travel mode and weakens the choice tendency towards alternative modes; this is found for public transport as well as for automobile choice. Gärling et al (2001), mention that frequent drivers who are forced to change to public transport for a short period continue to choose public transport more frequently than before the forced behavioural change. One might hence conclude that it is possible to induce a shift to more sustainable modes by encouraging or enforcing sustainable habits at one life stage.

In particular influencing younger people's habits appears to be important. According to e.g. Lanzendorf (2003) and Simma and Axhausen (2003), the way one grows up influences the way one travels, including habits and one's perspectives on the car, for the rest of one's life course. Other research from the public health domain (Millstein and Litt, 1990) shows that habits developed during the adolescence period will have a significant impact on the lifelong lifestyle of individuals. Furthermore, in particular commuting behavior is mostly habitual and habits are usually formed immediately after getting a job. These habits are expected to be influenced though by behavioural intentions developed before getting a job (Fujii and Gärling, 2003).

Thus the main foci of this research are university students where it is expected that their current 
Car Ownership Motivations Among Indonesian Students habits could influence their commuting behaviour not only presently but also after they graduate and obtain a job. We aim to distinguish factors that lead to actual car purchases among students and factors that lead to a desire to buy cars in the future and hence survey car owners as well as (current) non-car owners.

The structure of this paper is as follows: After this introduction, the second part of this paper will discuss previous research on car ownership forecasting and the motivation of individuals to buy cars. The following part discusses first characteristics of our study area, Bandung, Indonesia, before explaining the survey among students regarding their motivation to buy cars. We then describe first some aggregate statistics before employing principal component analysis to extract attitudinal factors that we hypothesize to determine car ownership decisions. These factors are subsequently used for regression and structural equation modelling (SEM) to understand car ownership factors. Finally, in Section 6 some conclusions and implications for transport planning are drawn.

\section{LITERATURE REVIEW}

To model nation-wide car ownership models GDP is generally found to be the most important factor (Tanner, 1978). After considerable trials of alternatives, Tanner proposed an equation for car ownership per person that includes, besides GDP, income per person, population density, growth of population over 10 years, the population proportions under 15 and over 64, and the percentage of self-employed people. Together these factors "explained" 89 percent of the variation in car ownership between countries. Studies about car ownership in developing countries also find GDP to be a key determinant to replicate and predict car ownership levels (Kahn and Willumsen, 1986; Button et al, 1993; Sillaparcharn, 2007).

Explaining car ownership levels by GDP development has also some important disadvantages though. The main weakness is that there is no reason to expect relations of this kind to apply unchanged over long time periods and in particular when saturation is being approached (Tanner, 1978). Further, and possibly more important, this method cannot be used for proposing sustainable transport policies. For example, the above mentioned literature on soft transport measures, shows that one does not have to (nor wants to) reduce the GDP to reduce car ownership levels. This explains the 
Car Ownership Motivations Among Indonesian Students motivation for more disaggregate studies on car ownership levels.

Several studies have been carried out to identify factors that affect car purchase decisions of individuals. Though some studies consider the decision to buy a vehicle or not, more often the focus has been on vehicle type choice, possibly due to easier access to data. Specifically multinomial logit (e.g. Lave and Train, 1979; Manski and Sherman, 1980; Mannering and Winston, 1985; Kitamura et al, 2000) and nested logit models (e.g. Hocherman et al, 1983; Berkovec, 1985; Berkovec and Rust, 1985; Mannering et al 2002) have been used to explain vehicle type choice. These models generally take vehicle attributes (e.g. operating cost, capital cost, and fuel efficiency), household characteristic, and principal driver characteristics as independent determinants.

The above literature does not consider individual behavioural intentions. According to the theory of planned behaviour (Ajzen, 1991), behaviour is constructed by intention and intention in turn is directly influenced by attitude towards the behaviour. This explains our motivation to study attitudes towards "the car in general" to understand car purchase decisions. We define attitudes here as "a psychological tendency that is expressed by evaluating a particular entity with some degree of favour and disfavour" (Eagly and Chaiken, 1993). In support of this approach a study on car usage based on attitudinal factors has been carried out by Choo and Mokhtarian (2004) who conclude that future models of vehicle type choice can be substantially more powerful with the inclusion of travel attitudes, personality, lifestyle, and mobility factors. Also Johansson et al (2006) conclude that attitudes and personality traits can make mode choice models more powerful, and socioeconomic variables may aid in forecasting such variables.

Some authors have hence applied attitudinal approaches to explain car purchase motivations. Steg (2003) studies the motivation of Dutch people to obtain a driving licence and concludes that PT cannot compete with cars as people favour cars more due its "status value". This status value, an expression of personal identity, is also known as symbolic factor of cars. Steg (2005) continued her research proving that people do not only drive their car because it is necessary to do so, but also because they love driving. The result shows that the symbolic/affective meaning of a car becomes the most important factor for decisions to obtain a driving licence, mode choice, car purchase decisions, followed by instrumental and independence factors respectively. 
Car Ownership Motivations Among Indonesian Students

Gatersleben (2011) confirms the Steg (2005) findings about social-symbolic factors related to car ownership and concludes that as long as the car is perceived as a symbol of success, road or public transport infrastructure investments are unlikely to result in major improvements to transport problems caused by excessive car ownership and usage. Weinberger and Goetzke $(2010 ; 2011)$ obtain two further significant results by studying the effect of past personal experience on auto ownership and the effect of peer behaviour on auto ownership decision. Firstly, people learn preferences and attitudes towards travel behaviour from transportation options in their past, then they carry these preference and attitudes into current situations which influence their car ownership decision. Secondly, people are influenced in their car purchase decisions by social peers and neighbours.

All of the studies on attitudes towards car have been carried out with data from developed countries and there appears to be a lack of work with survey data from developing countries with the exception of a study by Van and Fujii (2011). They studied attitudes towards private car usage, but not purchase, across six Asian countries with the surprising result that attitudinal variables had significant effects on the behavioural intention to commute by car only in Japan, China and Vietnam but not in Indonesia, Thailand and Philippines. In their research, based on constructing attitudinal factors through principal component analysis and regression analysis, three main dimensions of attitudes towards car are proposed and referred to as Symbolic/affective, Instrumental and Social Orderliness. The latter one has been found only in this study with Asian data. It comprises of beliefs such as environmental friendliness, safety, altruism, quietness etc. While previous studies mention about instrumental factors of cars as the main reason of cars usage and ownership, Van and Fujii (2011) suggest that symbolic/affective factors play a more important role although, this factor could not be observed to be significant in some countries.

Given the apparent importance of attitudinal factors to explain car ownership, this study aims to close the lack of literature on attitudes in developing countries. In contrast to Van and Fujii (2011) we focus on car purchase decisions. Our primary objective is to understand whether attitudinal factors found in particular by Steg (2005) as well as by Van and Fujii (2011) can be observed to be of any importance, in particular of more importance than income level. 
Car Ownership Motivations Among Indonesian Students

\section{SURVEY DESIGN AND IMPLEMENTATION}

\subsection{Study Area}

Bandung is located approximately $140 \mathrm{~km}$ south-east of Jakarta. It has a population of around 2.4 million people living in an area of $167.67 \mathrm{~km}^{2}$ which makes it the densest city in Indonesia with 14,283 people/ $\mathrm{km}^{2}$. Bandung has been famous as a fashion city since a long time. Because of its reputation many visitors come not only from Indonesia (especially Jakarta) but also from overseas, in particular Malaysia and Singapore, mostly for leisure and shopping purposes. This has generated high economic growth and an increase in freight as well as passenger traffic within the city and on motorways connecting Bandung with Jakarta. All of this has added to create severe traffic congestion within the city. The modal share in Bandung city, based on registered vehicles in 2010, is depicted in Figure 2, which shows the city is dominated by motorcycles and private cars.

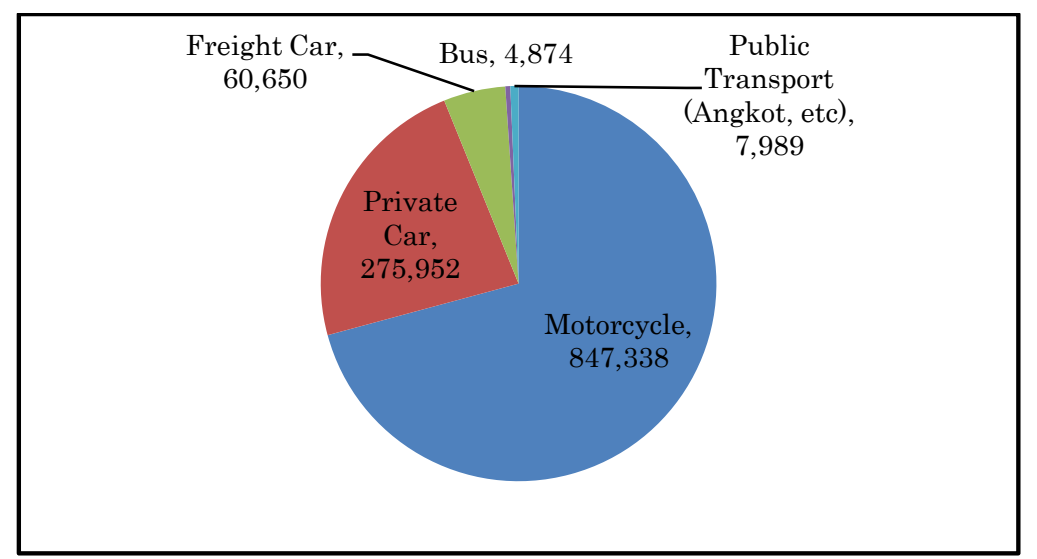

Figure 2. Modal Share in Bandung Based on Registered Vehicles in 2010. Source: Bandung City Government (2010)

Private cars make up around $23 \%$ of the modal share whereas buses and minibuses constitute less than $1 \%$ of the vehicle fleet. (Unfortunately data on person-trips or trip-km by modes are not available). Public transport in Bandung mainly consists of paratransit in the form of minibuses (Angkot). These have a capacity of 12-14 passengers and operate on fixed routes through various parts of the city (Joewono and Kubota, 2005). Angkot minibuses are allowed to stop everywhere without any restriction. Their departures are not fixed as the operators often wait until the vehicle is nearly full. Pradono et al (2009) discuss that the public transport system in Bandung is not designed to encourage mode choice and Tarigan et al (2010) reports that nearly 65\% of public transport users in 
Car Ownership Motivations Among Indonesian Students Bandung have an income nearly equal to or lower than the local standard minimum income level ${ }^{1}$ of IDR 939k (IDR 1,000k is about US\$100). The public transport network does not serve the city well and if residents do not want to, or can not afford to, purchase cars, they either have to stick to motorcycles or adjust their residential location. Therefore also for many students relying on PT alone is not a competitive alternative if one does not live very close to campus.

Our focus is on undergraduate students. There are three state universities and 78 private universities/academies in Bandung (Bandung City Government, 2010). Students' economic situation is obviously closely related to the support they obtain from their families. Intani (2009) reports that the parents of Bandung's public university students all have an income above the local standard minimum wage ${ }^{1}$. The average monthly income of students' parents is IDR9,443k, i.e. nearly ten times the minimum local income level. Intani (2009) also reports that students' monthly expenditure is on average 1,716k (with a range between IDR 500k- 4,200k). Pradono et al (2009) targeted students from two state universities (ITB and UNPAD) and two private universities (UNIKOM and UNISBA) and show that there is no significant difference in the socio-economic profile or modal split between the students from these four universities in Bandung. They report that $41,8 \%$ of the students own a car or motorcycle. Van and Fujii (2011) also interviewed students in Bandung and report that $10 \%$ own a car (they did not ask for motorcycle ownership). In our study described in the following we focus on students from one university only. This is clearly a limitation but partly due to the Pradono et al (2009) results we believe that our results have wider validity as we will discuss.

\subsection{Respondents}

The targets of our survey were students of Bandung Institute of Technology (ITB). Our survey focuses on undergraduates aged between 17 and 23 , as students, with the support of their parents, often purchase cars within their four years at university. In Indonesia, 17 is the minimum age to obtain a driving licence as well as for buying a car. The majority of the samples were obtained through surveys in classrooms at the end of lectures. Some additional surveys were obtained through randomly approaching students in communal areas. In total exactly 500 complete surveys could be obtained.

\footnotetext{
${ }^{1}$ Standard minimum income level also known in Indonesian as upah minimum propinsi (UMP). A law issued by the provincial government as a monthly salary guideline for full time employees.
} 


\subsection{Questionnaire design}

First the respondents were divided into two groups according to whether they own a car or not. Car owning respondents were asked 20 questions about their attitudes toward cars. It was emphasized that they should answer considering "cars in general". Respondents were asked to recall their attitude at the time of purchase as well as to provide their current attitudes. Each question was posed on a 7 point Likert scale with verbally defined endpoints (fully disagree - fully agree).

The first four items cars allow to express oneself, cars brings prestige, cars allow to distinguish oneself from others and cars allow to do adventurous things are taken with some adjustment from Steg (2005) who found that they loaded high in the construct symbolic/affective. Four further statements: cars are cool, cars are expensive to own and maintain, cars are fun to have and cars give an arrogant impression were taken from the attitudinal questions in Van and Fujii (2011) who also classified these items as symbolic/affective. The latter question did not load as high in Van and Fujii (2011) as the other three factors, possibly because "arrogance" is perceived often negative, whereas "cool" or "fun" have positive connotations.

A further item cars are comfortable was used in both Steg (2005) and Van and Fujii (2011) where Steg (2005) classified this item into her instrumental factor in contrast to Van and Fujii (2011), who found this factor correlates more with the symbolic/affective factor. The questions cars allow one to travel safely, cars allow one to pick up or see off others (from Steg, 2005) and cars are convenient (from Van and Fujii, 2011) were all classified as instrumental factors in previous research. Further questions taken from Steg (2005) are cars allow one to travel anytime, cars allow one to be independent, cars allow one to travel anywhere and cars help one to save time for travel which were found to form a factor referred to as independence.

As mentioned above, Van and Fujii (2011) propose that there is an additional attitudinal factor referred to as social-orderliness. To verify its importance we also include questions on whether respondents consider that cars are environmentally friendly, cars allow one to care about others, and cars are disturbing one's neighbourhood. A final item cars are trendy is included in accordance with Weinberger and Goetzke $(2010 ; 2011)$ who find that people are influenced in their transportation 
Car Ownership Motivations Among Indonesian Students decision by social peers and neighbours. Table 1 summarizes the attitudinal questions and in which literature they have been used before. In the second section of the survey, non car-owners were asked the same attitudinal questions and, to improve comparability, we emphasized again that answers should be based on their attitude towards "cars in general".

Table 1. Attitudinal questions towards cars used in survey; grouping according to previous literature.

\begin{tabular}{|c|c|c|c|}
\hline Symbolic/Affective & Instrumental & Independence & Social Orderliness \\
\hline $\begin{array}{l}\text { Cars allow to express oneself } \\
\text { (Steg, 2005) }\end{array}$ & $\begin{array}{l}\text { Cars are comfortable (Steg, } \\
\text { 2005; Van and Fujii 2011) }\end{array}$ & $\begin{array}{l}\text { Cars allow one to travel } \\
\text { anytime (Steg, 2005) }\end{array}$ & $\begin{array}{l}\text { Cars are environmentally } \\
\text { friendly (Van andFujii, 2011) }\end{array}$ \\
\hline Cars bring prestige & $\begin{array}{l}\text { Cars allow one to travel } \\
\text { safely (Steg, 2005) }\end{array}$ & $\begin{array}{l}\text { Cars allow one to be } \\
\text { independent }\end{array}$ & $\begin{array}{l}\text { Cars allow one to care about } \\
\text { others }\end{array}$ \\
\hline $\begin{array}{l}\text { Cars allow to distinguish } \\
\text { oneself from others }\end{array}$ & $\begin{array}{l}\text { Cars allow one to pick up or } \\
\text { see off others }\end{array}$ & $\begin{array}{l}\text { Cars allow one to travel } \\
\text { anywhere }\end{array}$ & $\begin{array}{l}\text { Cars are disturbing one's } \\
\text { neighborhood }\end{array}$ \\
\hline $\begin{array}{l}\text { Cars allow to do adventurous } \\
\text { things } \\
\text { Cars are cool (Van and Fujii, } \\
\text { 2011) }\end{array}$ & $\begin{array}{l}\text { Cars are convenient (Van and } \\
\text { Fujii, 2011) }\end{array}$ & $\begin{array}{l}\text { Cars helps one to save } \\
\text { time for travel }\end{array}$ & \\
\hline \multicolumn{4}{|l|}{$\begin{array}{l}\text { Cars are expensive to own } \\
\text { and maintain }\end{array}$} \\
\hline \multicolumn{4}{|l|}{ Cars are fun to have } \\
\hline $\begin{array}{l}\text { Cars give an arrogant } \\
\text { impression } \\
\text { Cars are trendy } \\
\text { (Weinberger and Goetzke, } \\
\text { 2010;2011) }\end{array}$ & & & \\
\hline
\end{tabular}

Non-car owners were asked similar questions regarding their desire to buy a car. In the final sections, all respondents were asked about their travel distance to come to university and their frequency of using public transport, "how often do you use public transport per week?". Further, we asked a limited number of questions about respondents' attitudes towards public transport in Bandung to verify whether limited PT is a reason for car ownership. These questions are also asked on a 7-point Likert scale. In particular we ask for their perception whether public transport is fast and reliable, variables that we refer to in the following as $P T$ is fast and PT is reliable. We note that students who do not or only seldom use public transport, might answer the PT questions based on what they have heard rather than what they experience. We perceive this difference though as not important for the purposes of this study as both direct as well as indirect experiences will have formed a respondent's attitudes (Eagly and Chaiken, 1993).The questionnaire concluded by asking for socio-demographic 
Car Ownership Motivations Among Indonesian Students characteristics including students' monthly income obtained jointly from parents, scholarships, part time jobs, etc. We provided five income categories 0-500,000 IDR (US\$0-50); US\$50-100; US\$100-250; US\$250-500; and more than US\$500. We do not have additional information about their parents' income, but believe that the students' available budget also, to some degree, reflects their parents' economic status. Only few undergraduate students obtain scholarships and the possibilities to significantly increase one's income by part-time jobs are limited during the first years of study. We do not include parking availability because in Bandung, as well as other parts of Indonesia it has never been a problem for car owners to find a parking space as parking restrictions in most places are not enforced.

\section{DESCRIPTIVE ANALYSIS}

\subsection{Sociodemographics}

Table 2 illustrates some of the socio-demographic characteristics of our respondents. The majority of the respondents are aged 19-21 $(\mu=19.83, \sigma=2.15)$. The youngest one is 17 which means all of them are allowed to apply for a car driving license. As the difference in age between the respondents is minor; it is not used in the subsequent analysis. We have slightly more males in our sample, in line with the overall student composition at ITB.

Table 2. Characteristic of Respondents.

\begin{tabular}{llrr}
\hline \multicolumn{1}{c}{ Descriptive Statistic } & Number & Percentage \\
\hline Total Sample & & 500 & $100 \%$ \\
Gender & Men & 282 & $56.4 \%$ \\
& Women & 218 & $43.6 \%$ \\
Car Ownership & Non Car Owner & 366 & $73.2 \%$ \\
& Car Owner & 134 & $26.8 \%$ \\
\hline
\end{tabular}

134 respondents, or $27 \%$ of the sample, are car owners. Based on the vehicle ownership statistics of students in Bandung discussed in Section 3.1, this seems fairly representative. Figure 3 groups the percentage of students owing a car based on income level. The category "more than US\$500" only contains four respondents, so that we combine it with the category "US\$250-500". Based on the above reported standard minimum income more than $50 \%$ of the students are below this. 
Car Ownership Motivations Among Indonesian Students If we compare this with the results of Tarigan et al (2010), this income distribution seems fairly representative.

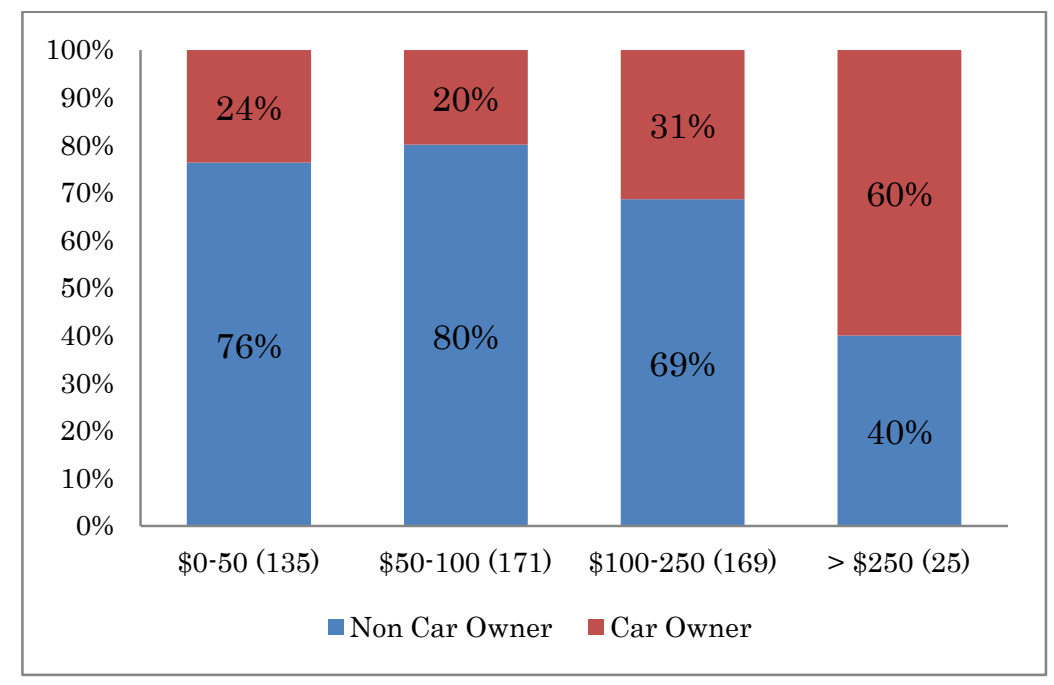

Figure 3. Car Ownership Ratio by Income Level (in brackets number of samples)

As one might expect, from the figure it can be seen that the number of car owners does increase with income level, though also low-income students own cars and not all of the students with a higher income own a car.

We further find that many respondents live fairly near the campus $(\mu=4.4 \mathrm{~km}, \sigma=5.1 \mathrm{~km}$, max $30 \mathrm{~km}$ ), reducing the need to own a car for commuting for some. Our respondents, both car owners and non car owners, further answer that they use PT on average 4.93 times per week, though this frequency varies significantly among respondents $(\sigma=4.9)$. As expected, respondents rate the service quality as fairly low ("PT is fast": $\mu=2.75, \sigma=1.47$; "PT is reliable": $\mu=2.94, \sigma=1.55$ ).

\subsection{Attitudinal Variables}

We analyse whether there are significant differences in attitudes towards cars between the car owners and non-car owners in our sample. Since our variables are ordinal we use the Mann-Whitney U test. As can be seen from Table 3, there are some significant differences between the two groups. 14 out of 20 attitudinal variables are significantly different at $5 \%$ level, one variable is significantly different at $10 \%$ level, while only the answers to five attitudinal questions are not significantly different.

In line with our expectation, in general car owners have more positive attitudes towards cars. 
They tend to agree more with the statements that cars allow one to travel anytime, travel anywhere, allow to be independent, and help save time to travel. These are independence reasons valued by car owners and possibly a reason for their eventual purchase of a car.

Table 3. Attitudinal differences between car owners and non-car owners

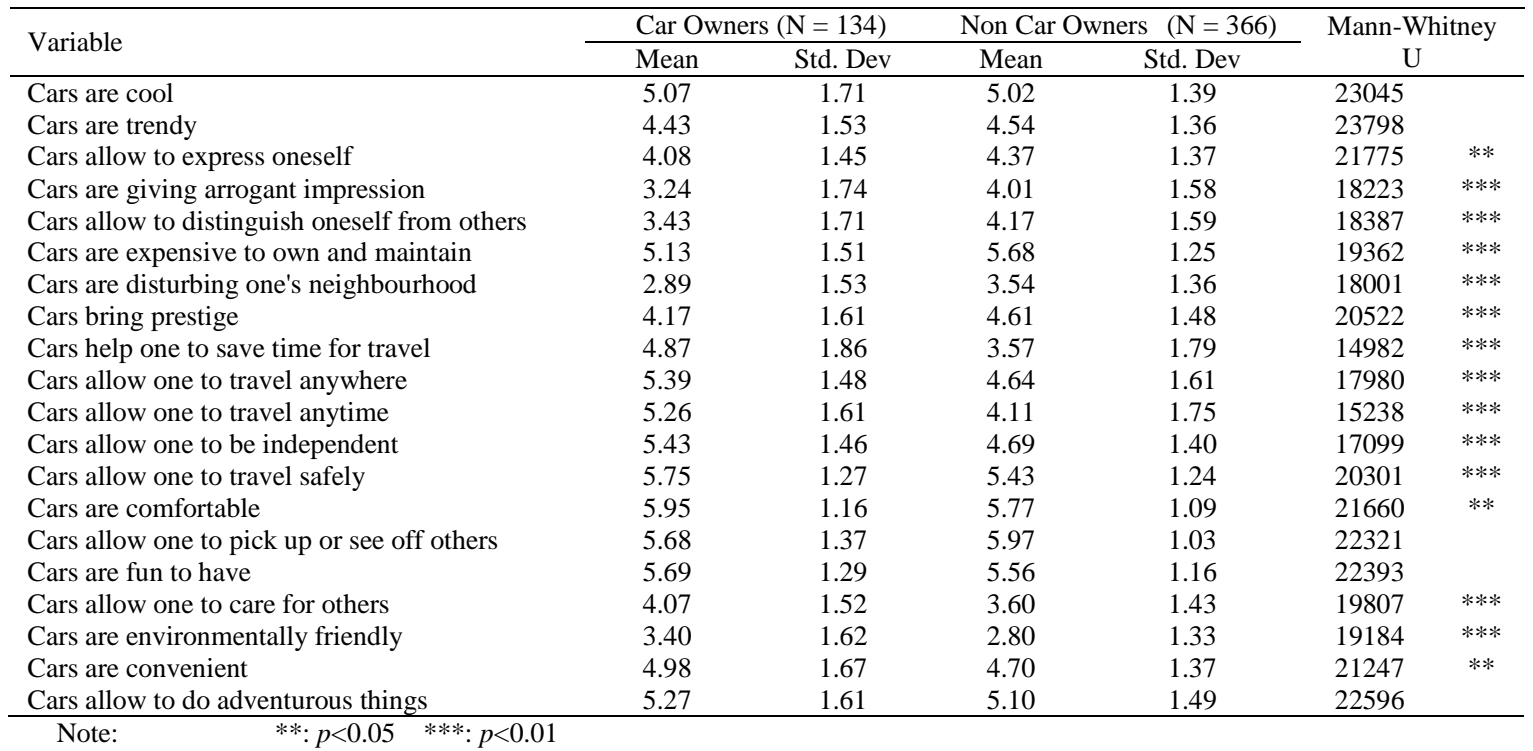

For the potentially negative images of cars such as cars allow to distinguish oneself from others and cars are expensive to own and maintain, car owners tend to disagree with these statements while non cars owner gives more value to it, which is also expected. Car owners also less agree with cars bring prestige and cars allow to express oneself, possibly because of a negative undertone perceived with these statements. Further, non car owners might overestimate the effect of car ownership on prestige and the possibility of self expression as they will not have had the experience of owning a car themselves.

Surprisingly, the statement cars allow one to pick up or see off others, a positive attribute of cars, is also more agreeable to non car owners than car owners. One might argue that this potential benefit of cars is not utilised as much as non car owners expect, explaining this result. Finally, regarding "direct negative effects" such as cars are environmentally friendly (reversed scale) and cars are disturbing one's neighbourhood non-car owners disagree more to the first statement and agree more to the second statements which is according to our expectations. We emphasise though that there various 
different possible explanations for this effect. Car owners might downplay the negative effects of their driving and/or not be aware of the side effects. Alternatively, one might argue that non-car owners are truly more aware of the externalities caused by driving. Yet another explanation would be that non car owners use the negative side effects as an excuse or "pretended argument" if they might not be able to afford a car. This projection of a negative image on an item that one currently does not own and can not afford to buy was termed "cognitive dissonance" by Festinger (1957). We return to this cognitive dissonance discussion also in the following discussion.

\section{CAR OWNERSHIP MODELS}

\subsection{Principal Component Analysis}

To construct uncorrelated factors of attitudes toward cars a principle component analysis (PCA) with varimax rotation was performed with the attitudinal variables. PCA is a method of data reduction where in the process it groups correlated variables into uncorrelated factors (Fabrigar et al 1999; Wright and Villalba, 2012). The results of the PCA can be seen in Table 4.

Table4. Rotated Factor Loadings on Attitudes toward Cars

\begin{tabular}{|c|c|c|c|c|c|c|}
\hline & Variables & $\begin{array}{c}\text { Symbolic/ } \\
\text { Affective } \\
(13.2 \%)^{\mathrm{a}}\end{array}$ & $\begin{array}{l}\text { Arrogant } \\
\text { Prestige } \\
(12.6 \%)\end{array}$ & $\begin{array}{c}\text { Independence } \\
(12.4 \%)\end{array}$ & $\begin{array}{l}\text { Comfort } \\
(11.5 \%)\end{array}$ & $\begin{array}{c}\text { Social/env. } \\
\text { Care } \\
(7.6 \%)\end{array}$ \\
\hline $\mathrm{X} 1^{\mathrm{b}}$ & Cars are cool & $.806^{\mathrm{c}}$ & -.008 & .022 & .270 & .058 \\
\hline $\mathrm{X} 2$ & Cars are trendy & .765 & .195 & .034 & .109 & .080 \\
\hline $\mathrm{X} 3$ & Cars allow to express oneself & .568 & .106 & .141 & .035 & -.093 \\
\hline $\mathrm{X} 4$ & Cars are giving arrogant impression & .263 & .732 & -.083 & -.054 & -.109 \\
\hline $\mathrm{X} 5$ & Cars allow to distinguish oneself from others & .370 & .688 & -.150 & -.158 & .100 \\
\hline X6 & Cars are expensive to own and maintain & -.121 & 638 & -.109 & .332 & -.177 \\
\hline $\mathrm{X} 7$ & Cars are disturbing one's neighborhood & -.056 & .578 & -.026 & -.217 & -.178 \\
\hline $\mathrm{X} 8$ & Cars brings prestige & .470 & .527 & -.223 & .145 & .182 \\
\hline $\mathrm{X} 9$ & Cars help one to save time for travel & .125 & -.191 & .764 & -.098 & .017 \\
\hline $\mathrm{X} 10$ & Cars allow one to travel anywhere & .048 & -.082 & .708 & .158 & .090 \\
\hline $\mathrm{X} 11$ & Cars allow one to travel anytime & .037 & -.200 & .707 & .124 & .209 \\
\hline $\mathrm{X} 12$ & Cars allow one to be independent & .003 & .137 & .608 & .352 & .072 \\
\hline $\mathrm{X} 13$ & Cars allow one to travel safely & .169 & -.183 & .065 & .694 & .186 \\
\hline $\mathrm{X} 14$ & Cars are comfortable & .027 & -.063 & .227 & .644 & .103 \\
\hline $\mathrm{X} 15$ & Cars allow one to pick up or see off others & .206 & .146 & .017 & .603 & -.209 \\
\hline $\mathrm{X} 16$ & Cars are fun to have & .479 & -.080 & .225 & .545 & -.054 \\
\hline $\mathrm{X} 17$ & Cars allow one to care for others & -.129 & -.052 & .128 & .188 & .762 \\
\hline $\mathrm{X} 18$ & Cars are environmentally friendly & .178 & -.166 & .192 & -.145 & .713 \\
\hline
\end{tabular}

At first factors were constructed based on all 20 attitudinal variables and 500 samples. The two variables cars are convenient, and cars allow to do adventurous things gave low loading factors 
Car Ownership Motivations Among Indonesian Students though, so that we excluded these two. All factors with eigenvalues larger than 1 are selected which leaves us with five constructs which explain $57.4 \%$ of the variance.

The first factor accounts for $13.2 \%$ of the variance. Variables loaded on this factor mostly refer to emotional perceptions such as the car being cool or trendy. Therefore this factor was named symbolic/affective in line with the Steg (2005) study. The second factor accounts for $12.6 \%$ of variance and describes negative associations with car ownership such as cars giving an arrogant impression, being a symbol of prestige and being expensive. Therefore this factor was named arrogant prestige. The third factor (explaining 12.4\% of variance) includes attitudes that were grouped as independence in previous research.

Variables loaded on the fourth factor (explaining 11.5\% variance) are cars allow traveling safely, are comfortable, allow picking up or seeing of others as well as are fun to have. As comfort and pleasure aspects for the driver as well as other passengers seem to be a central theme here, we refer to this factor as comfort. The last factor accounts for $7.6 \%$ of variance and includes the two items Cars allow one to care for others and cars are environmentally friendly. These variables were also key variables in Van and Fujii (2011) for their definition of a Social Orderliness factor. However, since our construct is slightly different, we prefer to name it Social/Env. Care in the following. These five attitudinal factors along with sociodemographic variables will be used for subsequent analysis to explain car ownership.

Table 5. Descriptive statistics of five attitudinal factors and sociodemographics

\begin{tabular}{|c|c|c|c|c|c|}
\hline Variable $(\mathrm{N}=500)$ & Mean & Min & Max & $\begin{array}{l}\text { Standard } \\
\text { deviation }\end{array}$ & $\begin{array}{l}\text { Std. Error of } \\
\text { Mean }\end{array}$ \\
\hline Symbolic/ Affective & 0.00 & -3.46 & 2.75 & 1.00 & 0.04 \\
\hline Arrogant Prestige & 0.00 & -4.47 & 2.33 & 1.00 & 0.04 \\
\hline Independence & 0.00 & -2.91 & 2.68 & 1.00 & 0.04 \\
\hline Comfort & 0.00 & -5.48 & 2.58 & 1.00 & 0.04 \\
\hline Social/Env. Care & 0.00 & -2.76 & 3.35 & 1.00 & 0.04 \\
\hline Commuting Distance & 4.36 & 0.08 & 30.00 & 5.10 & 0.23 \\
\hline PT is fast & 2.75 & 1.00 & 7.00 & 1.47 & 0.07 \\
\hline PT is reliable & 2.94 & 1.00 & 7.00 & 1.55 & 0.07 \\
\hline Frequency of using PT & 4.93 & 0.00 & 20.00 & 4.90 & 0.22 \\
\hline Monthly Income & 2.18 & 1.00 & 5.00 & 0.90 & 0.04 \\
\hline
\end{tabular}

Table 5 shows the descriptive statistic of variables used in the correlation analysis. The attitudinal factors were extracted using the Bartlett refined method (Bartlett, 1937). We choose this method 
Car Ownership Motivations Among Indonesian Students (instead of using for example weighted means) as it produces unbiased estimates of the true factor scores with sample mean zero and a standard deviation of one (for details we refer to Hersberger, 2005 in Distefano et al, 2009). Note that for income we use the 4 point ordinal scale as in Figure 3. Though this imposes the assumption of linearity between the categories we prefer this scale instead of a continuous scale or a dummy coded variable as firstly our categories have also been only broad and secondly, as discussed above, ideally for a precise income effect model one should have better knowledge of the parents' income situation. We further note that we found a better model fit by using the ordinal category. Needless to say, the ordinal variable is presumed to be strongly correlated with actual income, therefore we use the ordinal variable as substitute of actual continuous income that is more difficult to observe.

Table 6. Correlation between the five attitudinal factors and sociodemographics

\begin{tabular}{|c|c|c|c|c|c|}
\hline & $\begin{array}{l}\text { Commuting } \\
\text { Distance }\end{array}$ & $\mathrm{PT}$ is fast & PT is reliable & $\begin{array}{c}\text { Frequency of } \\
\text { using PT }\end{array}$ & $\begin{array}{l}\text { Monthly } \\
\text { Income }\end{array}$ \\
\hline Symbolic/ Affective & -0.02 & -0.06 & -0.05 & -0.01 & $0.10^{*}$ \\
\hline Arrogant Prestige & 0.02 & 0.01 & 0.04 & 0.01 & -0.08 \\
\hline Independence & -0.05 & -0.01 & -0.05 & 0.05 & 0.08 \\
\hline Comfort & 0.05 & 0.06 & 0.05 & -0.07 & 0.08 \\
\hline Social/ Env. Care & 0.09 & -0.02 & -0.04 & $-.012^{* *}$ & 0.04 \\
\hline Commuting Distance & & -0.01 & -0.05 & $-0.16{ }^{* *}$ & $-0.21^{* *}$ \\
\hline PT is fast & & & $0.63^{* *}$ & -0.04 & -0.04 \\
\hline $\mathrm{PT}$ is reliable & & & & 0.00 & -0.02 \\
\hline Frequency of using PT & & & & & 0.03 \\
\hline
\end{tabular}

Table 6 shows the correlation between these variables. (We omit correlation between attitudinal factors as these are (near) zero due to construction by PCA). We find non-significant correlations between attitudinal factors and socio-demographics except that the construct symbolic affective is, correlated with monthly income and that social/env. care is correlated with frequency of using PT. The positive significant correlation between symbolic affective and monthly income is understandable indicating that students from the highest income groups might consider it mandatory to own a car. The negative significant correlation between social/env. care and frequency of using PT is more difficult to explain. We suggest that these students either make in general less motorised trips or possibly this correlation supports the above proposed "cognitive dissonance" argument.

Some other expected significant correlations can be observed between the socio-demographic 
Car Ownership Motivations Among Indonesian Students variables. We observe that the higher the commuting distance the lower frequency to use PT. This might reflect the inconvenience of taking longer distance trips with public transport in Bandung. The negative significant correlation between commuting distance and monthly income is also expected as housing near the campus is very expensive.

\subsection{Car Ownership Models}

The above showed significant correlation between explanatory variables that might influence car ownership. In order to better understand indirect effects towards car ownership, especially related to income, we conduct a structural equation modelling (SEM) analysis. The model allows us further to directly estimate our latent attitudinal constructs ${ }^{2}$.

SEM is a multivariate regression in which the response variable in one regression equation may become predictor in another equation (Schumacker and Lomax, 2010). This allows us to account for correlations and to distinguish direct and indirect effects of our exogenous and latent variables on car ownership. Since our dependent variable is a dichotomous outcome (binary discrete choice model), we use the robust (mean- and variance adjusted) method of Weighted Least Square (WLS) also known as WLSMV (Muthén and Muthén, 2012). In general this method is preferable to Maximum Likelihood (ML) estimation when the data are severely nonnormal distributed (Olsson et al, 2000). Since car ownership is dichotomous we use SEM with binary probit regression for these paths towards our main dependent variable.

We use the five factors constructed by the above PCA analysis as a basis for determining exogenous latent variables. In addition we incorporate explanatory variables as exogenous variables including attitudes towards public transport. ${ }^{3}$ Since in our initial regression analysis we found that commuting distance has a negative significant correlation with frequency of using PT and monthly income we perform path analysis between these three variables in our SEM model. We hypothesize that monthly income might influence commuting distance since the housing location decision is often determined by income level; apartments closer to the campus area in general have higher prices in

\footnotetext{
${ }^{2}$ We initially conducted a binary logistic regression model using car ownership as the dependent variable (Belgiawan et al, 2011). However, a logistic regression model does not consider correlation between independent variables nor specify indirect paths which we consider important for our model.

${ }^{3}$ We tried to construct a latent variable "attitude to PT" with PT is fast and PT is reliable and to incorporate this into the SEM model, however, the goodness of fit of the model was low and the construct was not significant.
} 
Car Ownership Motivations Among Indonesian Students

Bandung thus we treat commuting distance as endogenous variable and monthly income as exogenous variable. We also hypothesize an indirect effect of commuting distance via frequency of using $P T$ on car ownership in line with our correlation results.

Table 7. SEM Model Estimation

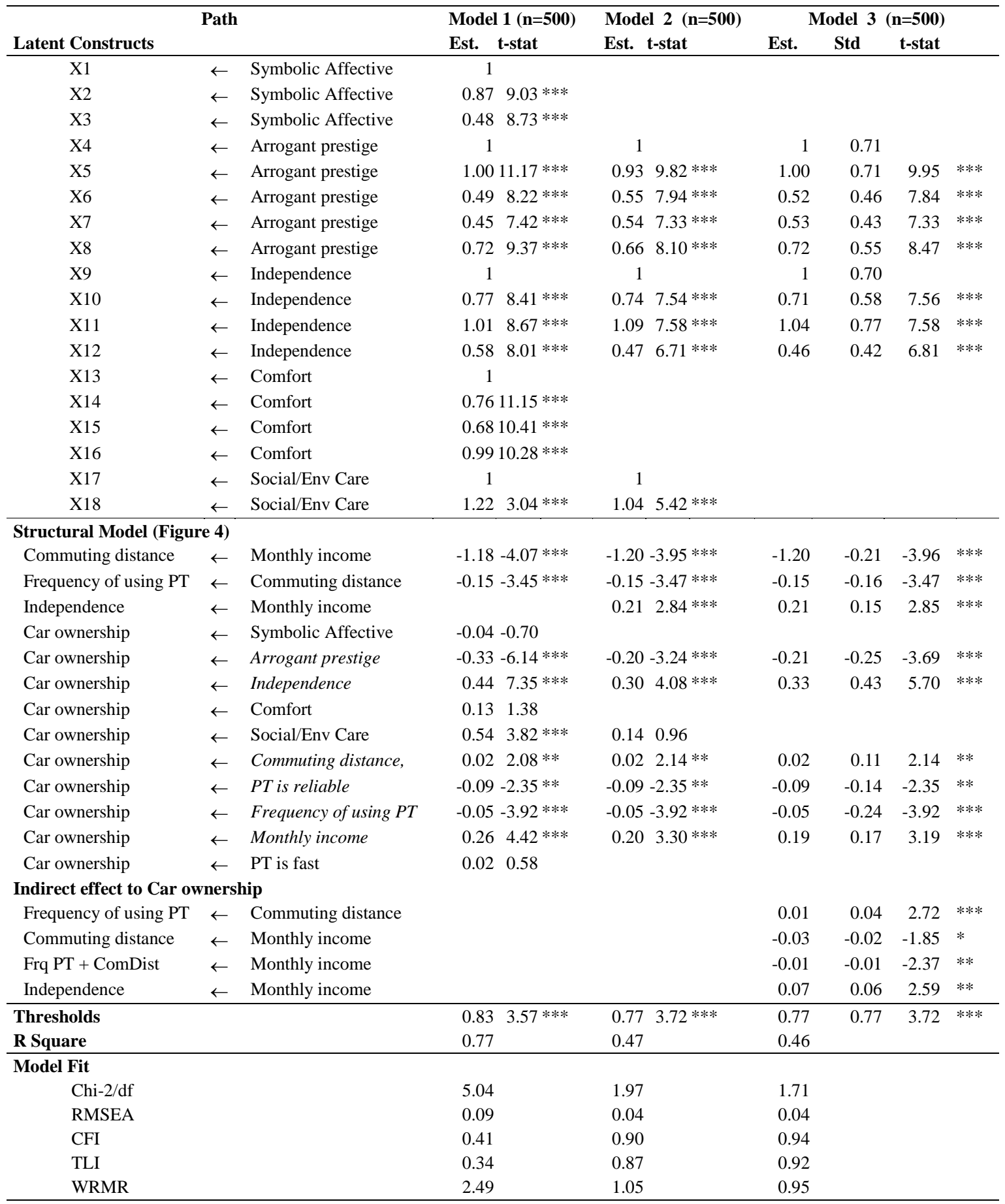

*. Correlation is significant at the 0.1 level

**. Correlation is significant at the 0.05 level .

***. Correlation is significant at the 0.01 level.

Italic represent significant factors and variables towards car ownership in Model 3 
Car Ownership Motivations Among Indonesian Students

We test different model specifications which are shown in Table 7. Model 1 is constructed without indirect paths as in Belgiawan et al (2011). The R-square is good, however other statistics suggest a low model fit $(\mathrm{RMSEA}=0.09 ; \mathrm{CFI}=0.410 \text {; TLI }=0.34 \text {; and WRMR }=2.49)^{4}$. We further find that the Symbolic/Affective does not explain car ownership in contrast to previous literature. Instead Arrogant Prestige is highly significant. Remembering that this construct relates to the negative aspects of Symbolic/Affective our result might hence suggests that it is rather the negative than the positive symbolic aspects that influence car ownership. Interestingly Comfort was further not significant possibly indicating that our student sample concerns less about these aspects.

Based on these observations we hence test alternative model structures. Model 2 provides a better model fit (reduced Chi-2/df; RMSEA $=0.04 ; \mathrm{CFI}=0.90 ; \mathrm{TLI}=0.87$; and WRMR $=1.05$ ). In this model we omit Symbolic affective and comfort as well as PT is fast since they were not significant in the first model. We further treat independence as endogenous variables influenced by monthly income based on correlations found in Table 6.

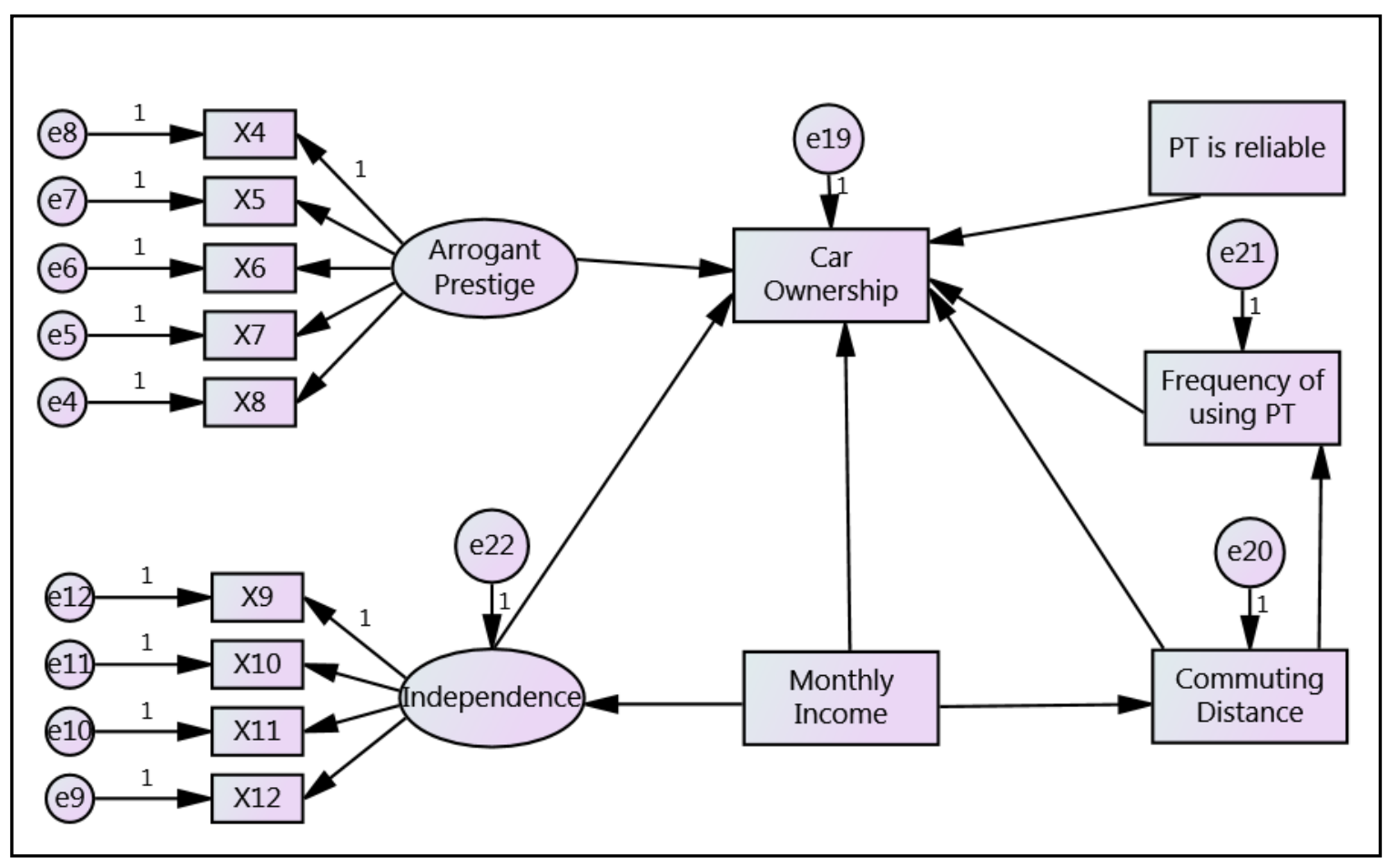

Figure 4. Car Ownership SEM Model 3

\footnotetext{
${ }^{4}$ In general with binary outcomes at $\mathrm{N}>250, \mathrm{CFI}>0.95$, TLI $>0.95$, RMSEA $<0.05$ and WRMR $<1$ can be indications of good models (Yu, 2002). CFI = Comparative Fit Index; TLI = Tucker-Lewis Index; RMSEA = Root-Mean-Square Error of Approximation; WRMR = Weighted Root Mean square Residual (WRMR is suitable to evaluate models with non-normally distributed outcomes)
} 
Car Ownership Motivations Among Indonesian Students

Our interpretation is that income level influences the car perception aspects such as save time to travel, can travel anywhere and can travel anytime which construct our independence factor. All variables are significant except for social/env. care. This might suggest that social and environmental aspects might be to some degree important to students but maybe not sufficiently to influence car ownership decisions. Omitting this factor then leads to our final Model 3 with the best model fit $($ RMSEA $=0.04 ; \mathrm{CFI}=0.94 ; \mathrm{TLI}=0.92 ;$ and WRMR $=0.95)$. The structure of this model is further illustrated in Figure 4.

\subsection{Discussion}

In our final model there are significant paths to car ownership from the attitudinal factors independence $(\mu=0.46, \sigma=1.32)$, arrogant prestige $(\mu=0.00, \sigma=1.17)$, PT is reliable as well as from frequency of using PT, commuting distance and monthly income. Arrogant prestige is constructed by the five attitudinal variables suggested by the PCA which are all found significant though the importance of the exogenous variables vary. Cars allow to distinguish oneself from others, are giving arrogant impression and bring prestige are weighted more than cars are expensive to own and maintain and are disturbing one's neighbourhood. This result though confirms our chosen construct name, i.e. the perception one conveys to others by owning a car is the central theme for this construct. For independence we find travel time related aspects more important in the construct.

Income directly and indirectly influences car ownership. The indirect paths are via commuting distance and frequency of using $P T$ with different sign and also through independence. Though we find this effect to be significant, it is a weak effect as the combined indirect effect of monthly income is only 0.03 . The path confirms our observation that high income students, probably especially those with parents out of town, choose to stay near the campus, while the lower income students choose to stay far from campus. 
Car Ownership Motivations Among Indonesian Students

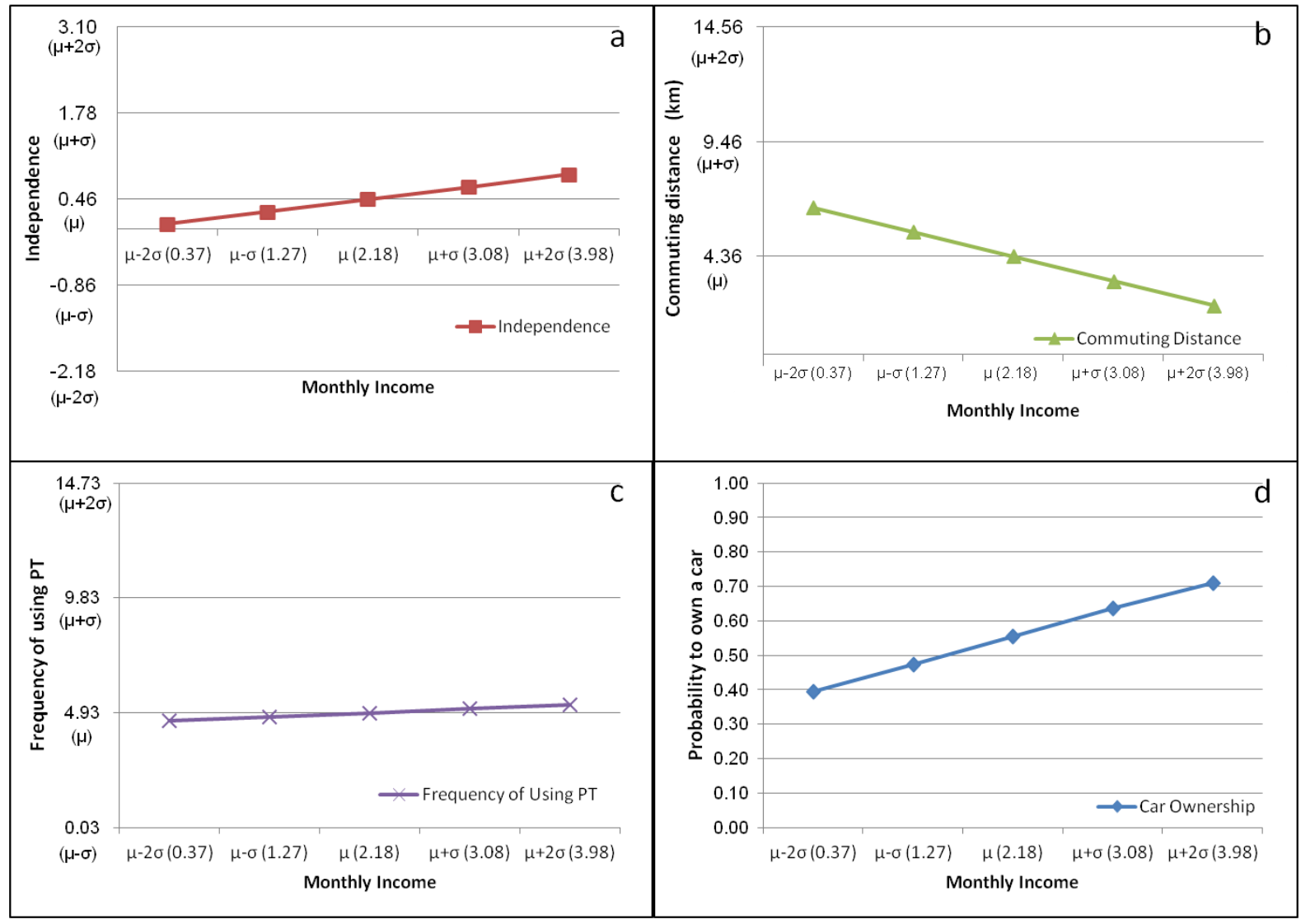

Figure 5 Combined effect of monthly income through (a.) Independence; (b.) Commuting distance; (c.) Frequency of using PT; on (d.) Car ownership intention.

In order to illustrate the estimated effect of income on other variables we consider a person with all variables at their mean as our reference point. We then vary monthly income by one and two standard deviations using our parameter estimates. Figure 5a illustrates the resulting increase in independence in terms of standard deviations. We find that a one standard deviation increase in income results in an increase of 0.14 standard deviations for independence. With the same methodology we find an opposite effect of income on commuting distance with larger effect in terms of standard deviation (0.21). In 5c, we find that PT is not highly influenced by the combined effect of monthly income and commuting distance. A standard deviation increase in income results in an increase of only 0.33 standard deviations, equivalent to 0.65 trips per month. Finally, $5 \mathrm{~d}$ illustrates the combined effect of income on car ownership taking all direct and indirect paths into account. That is all variables are at their mean, except for independence and commuting distance as well as frequency to use PT which deviate from their mean according to the estimated influence of income. We observe 
Car Ownership Motivations Among Indonesian Students that the combined effect of monthly income is quite high. That is, an increase in income by one standard deviation (or 0.90 categories on our 4 point income scale) results in an increase of $7 \%$ probability to own a car.

Our model suggests that compared to monthly income, commuting distance has less effect on car ownership. We further find that commuting distance negatively influences public transport usage as discussed before. The indirect effect of commuting distance on car ownership via frequency of using $P T$ is again very small (0.01). Frequency of using $P T$ and the perception that $P T$ is reliable both negatively influence car ownership with similar regression weights. This suggests that if PT is perceived more positively, the probability to use PT more and possibly not to own a car is also higher.

We find that, even controlling for the factors discussed so far, arrogant prestige significantly influences car ownership with a negative regression value of -0.21 . One might argue that in particular for this variable the causality is not clear. The interpretation in line with the model structure is that those who project a negative image on cars and car ownership tend to therefore also not purchase one. Another possibility could be again the afore mentioned cognitive dissonance argument. In other words non car owners might still desire a car but project a negative image on it as a way to reduce disappointment of not being able to afford one. We can not fully solve which of these two explanations is more likely with the data available to us.

Independence has a significant positive influence on car ownership. We remind that the construct refers to time and space travel flexibility which hence suggests that "classic utility factors" play a more important role for purchase decisions compared to the other attitudinal factors. We find the regression weight $(0.33)$ to be the highest parameter value among all the significant paths. This result is partly in disagreement with findings from Steg (2005) or Gatersleben (2011), who find that independence is less significant compared to symbolic affective. However, one should remember the different public transport situation in Bandung, Indonesia, compared to many European cities. Given the current PT conditions in Bandung one cannot guarantee punctual arrival when using minibuses. When travelling by car, one might also get stuck in congestion, however, at least one does not have the uncertainty of having to wait until a vehicle has collected enough passengers for the driver to decide to depart. Furthermore, as discussed above, the route network is fairly limited. 
Car Ownership Motivations Among Indonesian Students

To further illustrate the importance of attitudes and income Figures 6 shows the probability of students owning a car for varying the attitudes in units standard deviation and for different levels of monthly income (also in units of means plus/minus standard deviations). Similar to Figure 5 all other parameters have been held constant at their mean sample value. (Note that for independence the total effect equals the direct effect on car ownership). Figures 6-a and 6-b illustrates the effect of one and two standard deviation increases and decreases in the attitudinal construct and monthly income mean value.

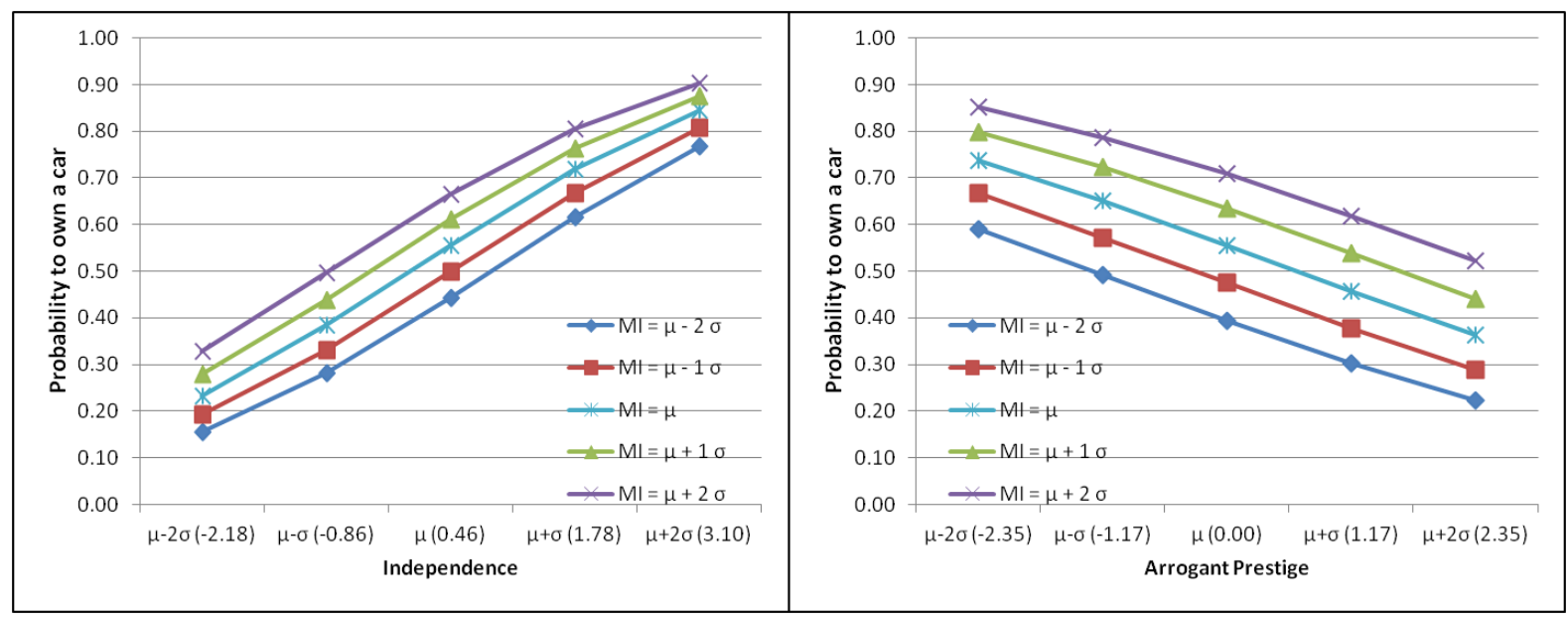

Figure 6 Probability to own a car by a change of standard deviation of (a.) Independence; and (b.) Arrogant Prestige

The figures clearly illustrate the relative importance of attitudes. For a "mean person" a standard deviation in independence perception increases the probability by nearly $20 \%$ whereas a standard deviation increase in income only increases the probability to own a car by about $10 \%$. The impact of Arrogant Prestige is not as large but still an increase in one standard deviation in this attitudinal construct has a larger impact than a standard deviation increase in income.

\section{CONCLUSIONS}

Our objective was to understand factors determining car purchase decisions among younger people in developing countries. Through a survey among Indonesian students in Bandung, asking for attitudes as well as socio-demographic characteristics we obtained several conclusions which we believe have 
Car Ownership Motivations Among Indonesian Students some policy implications and give possibly some hope that, at least to some degree, adequate transport policy could reduce the trend towards a rapid increase in car traffic.

Clearly with higher GDP and increasing income in South East Asian countries we expect the modal share of cars to increase. However, we find that attitudes are important determinants of car ownership and that attitudes such as the perception of whether the car is a prestige object and income are not significantly correlated, so that there might be some hope that rapid economic growth might not necessarily mean a motorization development as experienced in Western countries several decades ago. We find that independence related aspects are the most important factor for students to purchase a car. The result emphasizes that in Bandung and generally in situations where there are insufficient convenient public transport options, such services need to be improved first before one in fact has a choice.

Note that we further find that independence is also positively influenced by monthly income, therefore if monthly income changes also independence will. This finding might also have policy implications. With improving economic situations policy makers concerned about increasing car ownership do not only have to deal with the higher affordability of cars but also an increase in perception of how much independence a car can bring possibly due to the generally increased financial possibilities to travel. Therefore also for this reason it will be important to create early on a public transport system that can fulfil the more diverse travel needs of rapidly developing countries.

Further, the connection between income, commuting distance and car ownership lead to some obvious policy implications highlighting the need for affordable housing or dormitories near the campus.

The high importance of independence might though also imply that possibly the status symbol factor of cars is decreasing, at least for some parts of the population. This interpretation is supported by our findings regarding our construct arrogant prestige, which describes negative attitudes one has towards cars. We find arrogant prestige to be negatively significant, implying that those who think cars are arrogant also tend to not own one. We discuss some reservations regarding causality of this factor that should be explored with further research, but believe that, regardless of this discussion, this result indicates that students start to realise the negative societal effects of the car more. If the 
Car Ownership Motivations Among Indonesian Students negative side effects of cars for the society and city are highlighted, the car might eventually become a kind of "anti status symbol". Also the discussion on arrogant prestige and its correlation to behavior or car desire implies that some campaigns or public education to induce arrogant prestige to reduce car ownership might be helpful.

In line with these findings also Van and Fujii (2011) found that in some Asian countries the car has become less desirable compared to PT usage. As our survey is focused on young students one might even connect this to a discussion on values of "Generation Y". For example Newman (2011) argues that "previous generations found freedom and flexibility through the car. But Generation Ys find their freedom and flexibility by staying connected to their friends, family and workplaces through the various information devices - like their laptops, or i-phones." In how far hence this value shift could be used to encourage public transport usage should be further explored. Generally, we believe that our results suggest that, besides necessary improvements in the public transport system, soft policy measures such as communicative measures discussed in Taniguchi et al (2007) that aim to change the attitudes of younger people should also be considered as one way in developing countries to control the growth in car ownership and car usage.

Finally, in summary, we believe this paper contributes to explain determinant factors of car ownership decisions among Bandung students. We acknowledge that for wider generalisation of our results the data limitations of our study should be addressed. Besides repeating this study with additional data from a wider population group we believe an important further research direction is to include the "influence of others" more directly in car ownership modelling. Schmöcker et al (2013) discuss the role of "informational mass effect" in predicting mobility trends. They define this mass effect as positive influence to adjust one's choice to be in line with observed choices of others. Similarly Abou-Zeid et al (2013) review the influence of descriptive norms on mobility decisions, including car ownership. In current work therefore Belgiawan et al (2014) are exploring the role of such norms by expanding the work published here with an international survey.

\section{ACKNOWLEDGEMENTS}

The first author would like to thank the Lotte International Scholarship Foundation for supporting this 
Car Ownership Motivations Among Indonesian Students study through a personal scholarship. We would further like to acknowledge the support with funds from Grant-in-Aid for Young Researchers from Japan Society for the Promotion of Science (No. 23760481, Project Co-ordinator: Jan-Dirk Schmöcker, 2011-2014). The research has also benefited from discussions with Maya Abou-Zeid and Joan Walker.

\section{REFERENCES}

Abou-Zeid, M., Schmöcker, J.-D., Belgiawan, P.F. and Fujii, S. 2013. Mass effects and mobility decisions. In press with Transportation Letters: International Journal of Transportation Research (available online).

Ajzen, I. 1991. The theory of planned behavior. Organizational Behavior and Human Decision Processes 50 (2): 179-211.

Bandung City Government. 2010. Bandung in Figures 2010.

Bartlett, M. S. 1937. The statistical conception of mental factors. British Journal of Psychology, 28, 97-104.

Belgiawan, P.F., Schmöcker, J-D., and Fujii, S. 2011. Psychological Determinants for Car Ownership Decisions. Proceedings of the $16^{\text {th }}$ International Conference of Hong Kong Society for Transportation Studies (HKSTS), Hong Kong.

Belgiawan, P.F., S Schmöcker, J.D., Abou-Zeid, M., Walker, J., Lee, T-C., Ettema, D.F., Fujii, S. 2014. Car Ownership Motivations among Undergraduate Students in China, Indonesia, Japan, Lebanon, Netherlands, Taiwan, and U.S.A. Paper presented at the 93rd Annual Meeting of the Transportation Research Board. Washington D.C., U.S., January 2014 and in press with Transportation.

Berkovec, J. 1985. Forecasting automobile demand using disaggregate choice models. Transportation Research B 19(4): 315-329.

Berkovec, J., and Rust, J. 1985.A nested logit model of automobile holdings for one vehiclehouseholds. Transportation Research B 19(4): 275-285. 
Car Ownership Motivations Among Indonesian Students

Button, K., Ngoe, N., and Hine, J.L. 1993. Modelling vehicle ownership and use in low income countries. Transport Economics and Policy 27(1): 51-67.

Choo, S., and Mokhtarian, P. L. 2004. What type of vehicle do people drive? The role of attitude and lifestyle in influencing vehicle type choice. Transportation Research A 38(3): 201-222.

DiStefano, C., Zhu, M., and Mîndrilă, D. 2009. Understanding and Using Factor Scores: Considerations for the Applied Researcher. Practical Assessment, Research \& Evaluation, 14 (20). Available online: http://pareonline.net/getvn.asp?v=14\&n=20.

Eagly, A.H., and Chaiken, S. 1993.The Psychology of Attitudes. Orlando: Harcourt Brace and Company.

Fabrigar, L.R., Wegener, D.T., MacCallum, R.C., and Strahan, E.J. 1999. Evaluating the use of exploratory factor analysis in psychological research. Psychological Methods 4:272-299.

Festinger, L. 1957. A theory of cognitive dissonance. Stanford: Stanford University Press.

Fujii, S., and Gärling, T. 2003. Development of script-based travel mode choice after forced change. Transportation Research Part F 6: 117-124.

Gärling, T., Fujii, S., and Boe, O. 2001. Empirical tests of a model of determinants of script-based driving choice. Transportation Research F4: 89-102.

Gatersleben, B. 2011. The car as material possession: exploring the link between materialism and car ownership and use. In Auto motives: Understanding car use behavior, ed. Lucas, K., Blumenberg, E., and Weinberger, R., 137-148. Bingley, UK: Emerald Group Publishing Limited.

Hershberger, S. L. 2005. Factor scores. In B. S. Everitt and D. C. Howell (Eds.) Encyclopedia of Statistics in Behavioral Science. (pp. 636-644). New York: John Wiley.

Hocherman, I., Prashker, J. N., and Ben-Akiva, M. 1983. Estimation and use of dynamictransaction models of automobile ownership. Transportation Research Record 944: 134-141.

Hooper, D., Coughlan.J., and Mullen, M.R. 2008. Structural equation modelling: guideline for determining model fit. The Electronic Journal of Business Research Methods6 (1):53-60 
Car Ownership Motivations Among Indonesian Students

Indonesia Central Agency of Statistics. 2013. Number of motor vehicles by types, Indonesia 1987-2011. Available from <http://www.bps.go.id/eng/tab_sub/view.php?kat=2\&tabel=1\&daftar $=1 \&$ id_subyek=17\&notab=12>. (Accessed April 30 $0^{\text {th }} 2013$ ).

Intani, M.A.S.M. 2009. Identification of ability and willingness to pay of students living outside Bandung to live in an apartment in Bandung. Bandung: ITB. Undergraduate Thesis (in Indonesian).

Joewono, T.B., and Kubota, H. 2005. The characteristics of paratransit and non-motorized transport in Bandung, Indonesia. Journal of the Eastern Asia Society for Transportation Studies6: 262-277.

Johansson, M.V., Heldt, T., Johansson, P. 2006.The effects of attitudes and personality traits on mode choice. Transportation Research A 40: 507-525.

Khan, A., and Willumsen, L.G. 1986. Modeling car ownership and use in developing countries. Traffic Engineering and Control 27 (11): 554-560.

Kitamura, R., Golob, T. F., Yamamoto, T. and Wu, G. 2000. Accessibility and auto use in amotorized metropolis. Paper presented at the $79^{\text {th }}$ Transportation Research Board Annual Meeting, Washington, DC.

Lanzendorf, M. 2003. Mobility biographies: a new perspective for understanding travel behaviour. Paper presented at the 10th international conference on travel behaviour research, Lucerne, 10-15 August 2003.

Lave, C. A. and Train, K. 1979. A disaggregate model of auto-type choice. TransportationResearch A 13(1): $1-9$.

Mannering, F. and Winston, C. 1985. A dynamic empirical analysis of household vehicleownership and utilization. Rand Journal of Economics 16(2): 215-236.

Mannering, F., Winston, C., and Starkey, W. 2002. An exploratory analysis of automobile leasing by US households. Journal of Urban Economics 52(1): 154-176.

Manski, C. F. and Sherman, L. 1980. An empirical analysis of household choice among motor vehicles. Transportation Research A 14(5-6): 349-366. 
Car Ownership Motivations Among Indonesian Students

Millstein, S.G. and Litt, I. 1990. Adolescent health and health behaviors, S.S. Feldman, G. Elliott, Editors. In At the threshold: The developing adolescent. Harvard University Press, Cambridge, MA 431-456.

Muthén, L.K. and Muthén, B.O. 2012. Mplus User's Guide. Seventh Edition.Los Angeles, CA: Muthén \& Muthén.

Newman, P. 2011. High-tech draws new generation to trains. Article from $22^{\text {nd }}$ June in "The West Australian". Available from <http://au.news.yahoo.com/thewest/a/-/newshome/9683930/ high-tech-draws-new-generation-to-trains/> (Accessed May 2012).

Olsson, U.H.. Foss, T., Troye, S.V., and Howell, R.D. 2000. The performance of ML, GLS, and WLS Estimation in Structural Equation Modeling under conditions of misspecification and nonnormality. Structural Equation Modeling 7(4): 557-595.

Pradono., Rachmat, S.Y., and Pitaloka, N.D. 2009. Level of acceptance of the TDM implementation in Indonesian cities. Journal of the Eastern Asia Society for Transportation Studies 8:374-388.

Schmöcker, J.-D., Hatori, T. and Watling, D. 2014. Dynamic Process Model of Mass Effects. Transportation, 41(2), 279-304.

Schumacker, R.E. and Lomax, R.G. 2010. A Beginner's Guide to Structural Equation Modelling, Third Edition.New York: Routledge, Taylor and Francis Group.

Schwanen, T. and Lucas, K. 2011. Understanding auto motives. In: Auto motives: Understanding car use behaviours, Eds. Lucas, K., Blumenberg, E. and Weinberger, R., 3-38.

Sillaparcharn, P. 2007. Vehicle ownership modelling: a case study of Thailand. Transportation Research Record 2038: 98-104.

Simma, A., and Axhausen, K.W. 2003. Commitments and modal usage: analysis of German and Dutch panels. Transportation Research Record 1854: 22-31.

Steg, L. 2003. Can public transport compete with the private car. IATSS Research 27 (2): 27-35.

Steg, L. 2005. Car use: lust and must. Instrumental, symbolic and affective motives for car use. Transport Research A 39: 147-162. 
Car Ownership Motivations Among Indonesian Students

Taniguchi, A., Suzuki, H., and Fujii, S. 2007. Mobility management in Japan: its development and meta-analysis of travel feedback programs (TFPs). Transportation Research Record 2021: $100-117$.

Tanner, J.C. 1978. Long term forecasting of vehicle ownership and road traffic (with discussion). Journal of the Royal Statistical Society, Series A 14: 14-63.

Tarigan, A.K.M., Susilo, Y.O. \& Joewono T.B. 2010. Negative Experiences and Willingness to Use Paratransit in Bandung Indonesia: An Exploration With Ordered Probit Model. The 89th Annual Meeting of the Transportation Research Board. Washington DC, USA.

United Nations, Department of Economic and Social Affairs, Population Division. 2011. World population prospects: the 2010 revision. CD-ROM Edition.

Van, H.T and Fujii, S. 2011. A cross Asian country analysis in attitudes toward car and public transport. Journal of the Eastern Asia Society for Transportation Studies 9:411-421.

Van, T.H., Schmöcker, J.-D.and Fujii, S. 2009. Upgrading from motorbikes to cars: Simulation of current and future traffic conditions in Ho Chi Minh City. Proceedings of the Eastern Asia Transportation Studies 8: 335-349.

Weinberger, R. and Goetzke, F. 2010. Unpacking Preference: How Previous Experience Affects Auto Ownership. Urban Studies 47.10.

Weinberger, R. and Goetzke, F. 2011. Drivers of Auto Ownership: The Role of Past Experience and Peer Pressure. In Auto Motives: Understanding Car Use Behavior, ed. Lucas, K., Blumenberg, E., and Weinberger, R., 121-135. Bingley, UK: Emerald Group Publishing Limited.

Wright, D.B. and Villalba, D.K. 2012. Exploratory Factor Analysis. In Research Methods in Psychology, Fourth Edition ed. Breakwell, G.M., Wright, D.B., Smith, J.A., 279-318. Los Angeles, US: Sage Publications Ltd.

Yu, C.Y. (2002). Evaluating cutoff criteria of model fit indices for latent variable models with binary and continuous outcomes. Doctoral dissertation, University of California, Los Angeles. 